УДК: 004.832.23; 519.245; 519.676

JEL Classification: C 6

М. С. СІНИЦБКИЙ,

кандидат фізико-математичних наук, дочент, дочент кафедри інформаційних систем і технологій, Національна академія статистики, обліку та аудиту

Ф. В. МОЦНИЙ,

доктор фізико-математичних наук, професор, завідувач кафедри прикладної математики,

Національна академія статистики, обліку та аудиту

\title{
Вибір інвестиційних проектів методом Монте-Карло за наявності ризику
}

Кожний, хто живиться слабкістю до арифметичних методів отримання випадкових чисел, грішить поза усілякими сумнівами. Джон фон Нейман

Розглянута балансна модель інвестииійного проекту з дисконтуванням. Проаналізовані проекти зі слабкою і сильною кореляцісю параметрів чистої приведеноі вартості. Виявлена методом Монте-Карло чітка градація проектів за ризиком. Встановлено, щзо при виборі проекту необхідно враховувати кореляиійні ефекти, застосувавии базатовимірну імімацін.

Ключові слова: інвестииійний проект, чиста приведена вартість, ризики, метод Монте-Карло, псевдовипадкові числа, розклад А-Л. Холецького, похибки моделювання.

Постановка проблеми. Економічний аналіз останніх десятиріч переконливо свідчить про різке зростання кількості робіт, присвячених методу Монте-Карло при аналізі інвестищійних проектів. Досить пригадати фундаментальні праці [1-13], більшість 3 яких виконані в середовищі електронних таблищь [11]; алгоритми реалізації комп ютерного моделювання інвестиційних проектів [11-19], математичну та методологічну базу підготовки спеціалістів з інформаційних систем (UML, GPSS [20], Modelica [21] у складі платформ Piligrim [22], Model Vision Studium, AnyLogi, Arena [23]; математичні пакети MathCad [16] і Matlab [24,25]). Характерно, що у 40-50-ті роки минулого століття метод Монте-Карло застосовували переважно для розв' язання задач, пов' язаних з ядерними та іншими фундаментальними проблемами. Однак 3 появою у 2000 р. надбудови Oracle Crystal Ball до програми MS Excel [26] різко зросла кількість економічних і фінансових задач, розв 'язаних саме цим методом. Зазначимо також, що 32-х бітна версія 11.1.2 програми Oracle Crystal Ball є затребуваною з MS Office 2010 і до нині [26]. Більше того, випуск компанією Palisade Corporation додатку a) Risk (Risk analysis software using Monte Carlo simulation for Microsoft Excel and Microsoft Project) $[27,28]$ і проведена стандартизація інвестиційних проектів та технікоекономічних обгрунтувань управлінських рішень у сфері бізнесу на основі методики UNIDO (United Nations Industrial Development Organization) [8] як при розробці низки програмних комплексів управління фінансами підприємств (COMFAR, PROPSPIN, Alt-Invest, ИНЭК-Аналитик, Мастерская бизнес- планирования, Project Expert [29], так і управлінських проектів (MS Project, Primavera, Spider Project) обумовили подальший інтерес до досліджень у цьому напрямку [28, 29].

Статистичне моделювання випадкових величин залишається перспективним напрямком досліджень і по сей день, не дивлячись на те що імітаційне моделювання змістилося у бік нечіткої логіки Л. Заде [30-32]. Поява безкоштовних офісних продуктів, зокрема, Google Docs, Microsoft Office WebApps, Zoho Office Suite, Teamlab Office та інших [33], дозволили доозброїти малі компанії сучасним фінансово-статистичним інструментом і організувати їх ефективну співпрацю. Широкі можливості названих продуктів, а також Spreadsheet Google Docs [33] спонукали авторів до постановки і виконання запропонованої роботи, актуальність якої очевидна.

(C) М. Є. Сіницький, Ф. В. Моцний, 2017 
Аналіз останніх досліджень і публікацій. Критерієм визначення фінансової ефективності підприємств, оцінювання вартості компаній та вибору інвестиційних проектів слугує показник чистої приведеної вартості (NPV) [34,35]:

$$
N P V=\sum_{t=1}^{T} \frac{C F_{t}}{(1+r)^{t}}-C_{0},
$$

де $C F_{t}$ - чистий грошовий потік наприкінщі періоду $t ; T$ - термін інвестищійного проекту у періодах; $r$ - відсоткова ставка дисконтування; $C_{0}-$ початкові фінансові інвестиції $(t=0)$. В умовах лінійної амортизації $C F_{t}$ визначається таким чином $[34,35]$ :

$$
C F_{t}=N P+A-I
$$

Тут $N P$ - чистий прибуток; $A$ - амортизаційні відрахування; $I$ - разове початкове капіталовкладення на утворення основних фондів. У рамках діючого законодавства чистий прибуток модулюють так:

$$
N P=[Q \cdot(P-V C)-F C-A+L V] \cdot(1-I T)
$$

де $Q$ - обсяг збуту продукції у натуральних одиницях; $P$ - ціна одиниці продукції; $V C$ - умовно-змінні витрати на одиницю продукції; $F C$ - умовно-постійні витрати на випуск продукції; $L V$ - залишкова вартість (виручка від ліквідації) об' єкту; $I T$ - діюча ставка оподаткування прибутку.

Чутливість моделі до зміни параметрів задачі визначається коефіцієнтом еластичності [36]:

$$
E_{j}=\frac{\partial Y}{\partial x_{j}} \cdot \frac{x_{j}}{Y}
$$

або середнім значенням:

$$
\bar{E}_{j}=\frac{\partial Y}{\partial x_{j}} \cdot \frac{\bar{x}_{j}}{\bar{Y}}
$$

де $\frac{\partial Y}{\partial x_{j}}$ - частинна похідна від обраного показника ефективності проекту (у нашому варіанті- $N P V$ ) за параметром незалежної змінної моделі $x_{f}, \bar{Y}$ i $\bar{x}_{j}-$ відповідні середні арифметичні. Знаючи коефіціснт еластичності, можна встановити основні фактори, що впливатимуть суттєво на кінцевий результат. Чим менше коефіцієнт еластичності, тим меншими будуть ризики за даним параметром. Як слідує з основ метрології [37], дисперсія спостережуваної величини $Y$ (похибка вимірювання чи прогнозу величини) залежить від дисперсій незалежних змінних $x$, Для оцінки відгуку моделі на вхідні збурення недостатньо знати чутливість їі параметрів до цих збурень. Треба враховувати ще реальні точкові $\sigma_{x i}^{2}$ чи інтервальні $\pm t^{*} \cdot \sigma_{x y}^{2}$ оцінки розкиду параметрів $x_{j}$ ( $t^{*}$ - величина, що залежить в1д рівня довірчої ймовірності), які часто ототожнюють 3 мірами ризику. У переважній більшості випадків достовірний матеріал невідомий. Тому для розрахунків характеристики $\sigma^{2}$ застосовують статистичне моделювання випадкових величин - метод Монте-Карло (також відомий як метод Monte Carlo Simulation (моделювання Монте-Карло)), запропонований Н. Метрополісом, С. Уламом і Дж. фон Нейманом [38] - учасниками Манхеттенського проекту створення атомної бомби. Серцевину цього методу складають випадкові числа та їх генерація. Для реалізації методу Монте-Карло був використаний один з перших у світі комп'ютерів MANIAC (Mathematical Analyzer). 3 того часу цей метод широко застосовується у різних областях науки і техніки (ядерна та статистична фізика, прикладна математика (обчислення визначених інтегралів, задача комівояжера, крайові задачі, аналіз зображень, ланцюги Маркова), оптика, фізична і хімічна кінетика, генетика, моделювання бойових дій, розпізнавання образів, тестування, системи штучного інтелекту, теорія масового обслуговування, оцінка фінансових ризиків та інші). Метод Монте-Карло дозволяє розглянути усі можливі наслідки математичних розв'язків та оцінити вплив 
ризиків, забезпечуючи у такий спосіб більш високу ефективність прийняття рішень в умовах невизначеності.

Таким чином, застосування цього методу цілком слушне для розв'язання в першу чергу тих математичних задач, де має місце їх опис на основі теорії ймовірностей $\mathrm{i}$ математичної статистики.

Перші пакети прикладних програм (MCNP (Monte-Carlo N-Particle Transport Code, «Los-Alamos National Laboratory»); GEANT (Geometry and Tracking , «CERN»); $M C U$ (Monte-Carlo Universal (Науково-дослідний центр «Курчатовсыкий інститут» (Москва)), були розроблені для розв язання задач військового спрямування. 3 часом їх алгоритми стали доступні більш широкому загалу. Подальший розвиток методу Монте-Карло пов'язаний зі створенням алгоритмів імітації відпалу (Simulated Anneling), або методу Монте-Карло на ланцюгах Маркова (MCMC-Markov Cain Monte-Carlo Methods) [39], що часто використовується у комбінації з методологією Байєса.

Загальна схема алгоритму методу Монте-Карло така: 1. Конструюють для невідомої величини $x_{\text {випадкову величину }} \xi=\xi_{1}+\xi_{2}+\ldots \xi_{n}$
з математичним сподіванням:

$$
M \xi \approx M x \approx \bar{x}
$$

для визначеної кінцевої дисперсії $D \xi=D$ невідомої величини $x$.

2. Генерують багаторазово на ЕОМ незалежні реалізації $\xi$, розподіл яких співпадає 3 розподілом випадкової величини $\xi$, і обчислюють вибіркове середнє:

$$
\bar{x}=\frac{1}{n} \cdot \sum_{i=1}^{n} \xi_{i}
$$

де $n$ - кількість генерацій (прогонів).

3. За законом великих чисел (див., наприклад [40-42]), якщо математичне сподівання випадкової величини $\bar{\xi}$ існує, то вибіркове середнє $\bar{x}$ збігає до невідомої величини $x з$ імовірністю 1 (у противному випадку $\lim \sup x \Rightarrow \infty)$.

4. За центральною граничною теоремою А.М. Ляпунова [41-43], якщо у послідовності $x_{1}, x_{2}, \ldots x_{n}$ випадкові величини незалежні, однаково розподілені $i$ існують скінченні математичні сподівання $M\left(x_{j}\right)=\alpha$ і середні квадратичні відхилення $\sigma\left(x_{i}\right)=\sigma$, то $\frac{\bar{x}-x}{\sqrt{n} \cdot \sigma} \Rightarrow N(0,1)$ за розподілом при $n \Rightarrow \infty$, тобто середнс арифметичне $\bar{x}$ випадкової величини збігає за ймовірністю до випадкової величини $x$, розподіленої за нормальним стандартним законом Гауса $(\mathrm{a}=0, \sigma=1)$.

5. Середнє квадратичне відхилення середнього арифметичного $\bar{x}$ випадкової величини $x$ обчислюється за формулою:

$$
\sigma(\bar{x})=\frac{\sigma}{\sqrt{n}} .
$$

6. Похибка розрахунків за методом Монте-Карло така:

$$
\varepsilon \approx \sqrt{\frac{d}{n}},
$$

де $d$ - стала. Із формули (9) слідує, що для збільшення на порядок точності розрахунків, необхідно збільшити на два порядки кількість вимірів, тобто для застосування методу Монте-Карло необхідно мати потужний розрахунковий ресурс.

7. Імовірність відхилення за абсолютною величиною середнього арифметичного від математичного сподівання $M(x)$ нормально розподіленої випадкової величини $x$ визначається теоремою П.Л. Чебишева $[40,41]$ :

$$
P(|\bar{x}-M(x)|<\varepsilon)=2 \Phi(\varepsilon / \sigma(x)=2 \Phi(\varepsilon \sqrt{n} / \sigma)=2 \Phi(t),
$$

де $\Phi(t)$ - функція Лапласа. За правилом «трьох сигма» [41], якими 6 не були величини $x, \xi$ і $\varepsilon$ це відхилення не перевищуватиме трьохкратне середнє квадратичне відхилення, а ймовірність такого відхилення дорівнюватиме 0,9972 . 
Отже, базою для методу Монте-Карло є граничні теореми теорії ймовірностей, із яких випливає, що при великому числі дослідів частота події наближатиметься до ймовірності, а середнс арифметичне спостереженої випадкової величини - до ії математичного сподівання.

Успішна реалізація методу Монте-Карло залежить від точності виконання рівняння (6), оскільки комп'ютерний алгоритм генерує фактично псевдовипадкову величину [44]:

$$
x=\varphi(\vec{\xi}),
$$

де $\vec{\xi}-$ випадковий вектор чи випадкова послідовність чисел із заданим розподілом, $\varphi(\vec{\xi})$ - функція, яка задає алгоритм генерації випадкових чисел.

Визначальним моментом методу Монте-Карло є забезпечення ефективної генерації псевдовипадкової величини, шо має сталий статистичний розподіл.

Єдиної теорії генерації псевдовипадкових чисел не існує. Жоден детермінований алгоритм не генерує випадкові числа, а лишень апроксимує деякі їх властивості [45]. Одним 3 перших алгоритмів формування псевдовипадкових чисел був метод середини квадратів $[45,46]$. Але цей алгоритм не оправдав себе, бо в результаті прогонів отримували більше малих чисел ніж мало бути. Тому запропонували інші методи, зокрема, лінійний конгруентний метод формування псевдовипадкових чисел (метод відрахувань, порівнянь) $[47,48]$. У цьому методі цілі чиссла $\xi_{1}, \xi_{2}, \ldots$ обчислюються за рекурентною формулою:

$$
\xi_{i+1}=\left(a * \cdot \xi_{i}+b\right) \cdot \bmod m,
$$

де $a^{*}, b, m$ - деякі сталі, що визначають період породження генератором псевдовипадкових чисел. Так, у програмі $M C N P a^{*}=5^{15}, m=2^{47}$. Оскільки залишок від ділення завжди менше дільника, то $0 \leq \xi_{i} \leq m-1$. Якщо покласти $x_{i+1}=\xi_{i+1} / m$, то псевдовипадкові числа розподілятимуться рівномірно і знаходитимуся в інтервалі $(0,1)$. Цей варіант формування псевдовипадкових чисел використовується у генераторах найбільш часто. Двійкове уявлення кожного випадкового числа $x \in(0,1)$ має вигляд:

$$
x=0, x^{(1)}, \ldots, x^{(k)}, \ldots=\sum_{k=1}^{\infty} x^{(k)} \cdot 2^{-k}
$$

де $k$ - номер розряду. Кожний розряд $x^{(k)}$ мантиси числа $x$ дорівнює 0 , або 1 . Для того щоб випадкова величина була рівномірно розподіленою в інтервалі $(0,1)$ необхідно і достатньо [44] щоб двійкові цифри $x^{(1)}, x^{(2)}, \ldots, x^{(\mathrm{k})}$ відповідали послідовності незалежних випадкових величин Бернуллі з імовірністю успіху $1 / 2$, тобто $P\left(x^{(k)}=1\right)$ $=P\left(x^{(k)}=0\right)=1 / 2$. Саме така ймовірність притаманна парі подій «так-ні», або «ні-так», які легко формуються пристроями 3 двома сталими станами (наприклад, тригерами). Генерація псевдовипадкових чисел здійснюється як на апаратному рівні (процесори X86, мікрочіпи Intel серій $810,815,820,840,850,860$ тощо), так і за допомогою програм. Слід зауважити, що параметр $m$ у формулі (12) відповідає довжині випадкової послідовності, за межами якої числа починають повторюватися. Тому цей параметр має бути як найбільшим. Число $k$ обмежують довжиною процесорного слова. Для програм, що реалізують генерацію псевдовипадкових чисел для 32-розрядних операційних систем, $k=31$ (крайній лівий біт - знаковий), а найбільше число $m=2^{31}$, причому за $a^{*}$ обирають числа $8 \mathrm{k}+3$, або $8 \mathrm{k}+5$. Тоді мультиплікативний генератор $(b=0)$ матиме період $2^{29}$, а інтервал псевдовипадкових чисел відповідатиме $(1 ; 2147483647)$, або у нормованому вигляді $(0 ; 0,999999)$.

Відомі кращі генератори псевдовипадкових чисел ніж лінійний конгруентний, наприклад, «вихор Мерсена», шо має період $2^{19937}$ і в 2-3 рази більш швидкий [49]. Однак завдяки своїй простоті та високій швидкості генерації псевдовипадкових чисел саме лінійно-конгруентний генератор використовуються у MS Excel i Google Docs, шо реалізований у вигляді функцій $C J Ч И C()$ і $R A N D()$, відповідно. Рівномірний розподіл у межах інтервалу $\left(x_{\min }, x_{\text {max }}\right)$ генерують, використовуючи метод інверсії $[44,45]$. Так, y MS Excel: ,

$$
x_{i}=\left(x_{\max }-x_{\min }\right) \cdot C Л Ч И С О ~+x_{\min },
$$




$$
\begin{aligned}
& \text { або } x_{i}=\text { СЛУЧМЕЖДУ }\left(x_{\min } ; x_{\max }\right) ; \\
& \text { тоді як у Google Docs: } \\
& x_{i}=\left(x_{\max }-x_{\min }\right) \cdot R A N D O+x_{\min }, \\
& \text { або } x_{i}=R A N D B E T W E E N\left(x_{\min } ; x_{\max }\right)
\end{aligned}
$$

За допомогою відповідних функцій та надбудови «Пакет аналізу» у програмі MS Excel можна згенерувати при необхі дності нормальний, логнормальний, рівномірний, трикутниковий, Бернуллі, біноміальний, Пуассона, дискретний та інші розподіли [50]. Можливість використати при необхідності один із названих розподілів $\epsilon$ особливо цінною, коли розподіли первинних параметрів моделі за природою нерівномірні. Отже, автоматизація генерації псевдовипадкових чисел спрощує розрахунки за методом Монте-Карло

Ризики є частиною будь-яких прийнятих рішень. Їх аналізу і оцінці методом Монте-Карло присвячена низка монографій, навчальних посібників і наукових статей [51-62]. Показано, що цей метод доцільно застосовувати, що особливо важливо, в умовах невизначеності і підвищеного ризику $[51,52,57,60]$; при виборі оптимальної методики оцінки фінансових ризиків $[53,54]$; отриманні прибутку чи втрат від придбання патенту [60] тощо.

Мета досліддження - вивчити методом Монте-Карло вибір інвестиційних проектів зі слабкою і сильною кореляцією параметрів чистої приведеної вартості за наявності ризику, використовуючи програмне середовища MS Exel/Google.

Виклал основного матеріалу. Недоліком показника $N P V \in$ те, що цей показник не враховус ймовірності майбутніх подій, тобто пов'язаних з ним ризиків. Тому в [35] ця формула була модифікована введенням залежності відсоткової ставки дисконтування від темпу інфляції у вигляді:

$$
\hat{r}=\left(r-i_{t}\right) /\left(1+i_{t}\right),
$$

де $i_{t}-$ темп інфляції в періоді $t$. Це в певній мірі компенсувало можливі втрати інвестора від впливу інфляції на ціну проекту. Однак інвестор не може передбачити інші ризики, обумовлені, наприклад, нестабільністю ринків товару, праці, обмінного курсу валюти тощо.

Для оцінки можливих наслідків від збурення сталих значень параметрів у формулах (1) i (2) використали стохастичне моделювання за методом Монте-Карло. Вихідні дані моделей інвестиційних проектів представлені в табл. 1. Коефіцієнти еластичності розрахували для 1\% межі відхилення параметрів від їх номінального значення. Вибір параметрів здійснювали у такий спосіб, щоб величина $N P V$ усіх трьох проектів відрізнялася мало і не працювала таким чином можливість вибору проекту за цією величиною. За таких умов, як видно з табл. 1 , найменш ризиковим $€$ проект A, бо йому відповідає найменший коефіцієнт еластичності.

Номінальні значення параметрів та коефіціснтів еластичності

Табличя 1 порівнювальних інвестиційних проектів

\begin{tabular}{|l|r|r|r|r|r|r|}
\hline \multirow{2}{*}{$\begin{array}{c}\text { Параметр / } \\
\text { показник }\end{array}$} & \multicolumn{2}{|c|}{ Проект А } & \multicolumn{2}{c|}{ Проект В } & \multicolumn{2}{c|}{ Проект С } \\
\cline { 2 - 7 } & Значення & $\begin{array}{c}\text { Еластич- } \\
\text { ність }\end{array}$ & Значення & $\begin{array}{c}\text { Еластич- } \\
\text { ність }\end{array}$ & Значення & $\begin{array}{c}\text { Еластич- } \\
\text { ність }\end{array}$ \\
\hline 1 & 2 & 3 & 4 & 5 & 6 & \multicolumn{1}{c|}{7} \\
\hline$Q$, шт. & 20295 & 0,024 & 9810 & 0,024 & 14964 & 0,024 \\
\hline$P 1$, грн/шт. & 35 & 0,048 & 125 & 0,083 & 65 & 0,066 \\
\hline$P 2$, грн/шт. & 42 & 0,058 & 150 & 0,100 & 78 & 0,079 \\
\hline$P 3$, грн/шт. & 50,4 & 0,069 & 180 & 0,120 & 93,6 & 0,095 \\
\hline$V C$, грн/шт. & 25 & $-0,034$ & 115 & $-0,077$ & 55 & $-0,056$ \\
\hline$r, \%$ & 20 & $-0,014$ & 20 & $-0,009$ & 20 & $-0,009$ \\
\hline$i_{*} \%$ & 12 & 0,006 & 12 & 0,006 & 12 & 0,006 \\
\hline
\end{tabular}


ВИБІР ІНВЕСТИЦЙНИХ ПРОЕКТІВ МЕТОДОМ МОНТЕ-КАРЛО ЗА НАЯВНОСТІ РИЗИКУ

Продовження табл. 1

\begin{tabular}{|l|r|r|r|r|r|r|}
\hline \multicolumn{1}{|c|}{2} & \multicolumn{1}{c|}{3} & 4 & 5 & 6 & \multicolumn{1}{c|}{} \\
\hline$t$, років & 3 & $-0,041$ & 3 & $-0,043$ & 3 & $-0,042$ \\
\hline$F C$, грн. & 200000 & $-0,020$ & 200000 & $-0,014$ & 200000 & $-0,014$ \\
\hline$A$, грн. & 0 & 0 & 0 & 0 & 0 & 0 \\
\hline$I T, \%$ & 30 & 0,006 & 30 & 0,004 & 30 & 0,004 \\
\hline$L V$, грн. & 0 & 0 & 0 & 0 & 0 & 0 \\
\hline$I_{n}$ грн. & 0 & 0 & 0 & 0 & 0 & 0 \\
\hline$N P V$, грн & 269910 & 0,122 & 269915 & 0,207 & 269919 & 0,165 \\
\hline
\end{tabular}

Джерело: власна розробка авторів

Розглянемо тепер ситуацію, коли параметри $N P V 3$ максимальними коефіціснтами еластичності матимуть певну невизначеність (ризики) у межах до 30\% . Згенеруємо їх за формулами (14) і (16), використавши 10000 прогонів. Отримані у кожному прогоні псевдовибіркові числа підставимо у формулу (1) і сформуємо у такий спосіб псевдовибірку $N P V$. Вибіркові статистики і число випадків $N P V<0$ для цих проектів разом із варіаціями їх параметрів у 10\%, 20\% і 30\% для максимальних коефіцієнтів еластичності представлені в табл. 2. Помічаємо, що коефіцієнт варіації $v_{N P V}$ приблизно в 4 рази перевищус варіації параметрів проекту А, в 7 разів - проекту В і в 5 разів - проекту C. Отже, виявлена чітка градація досліджуваних проектів за ризиком, що аналогічна знайденій за коефіцієнтами еластичності. Однак, забігаючи наперед відзначимо, що метод Монте-Карло є більш інформативним щодо ймовірнісних показників, надійність яких залежить від того, наскільки розподіли сформованих значень параметрів і $N P V$ відповідатимуть реальним.

Таблиця 2

Вибіркові статистики порівнюваних інвестиційних проектів

\begin{tabular}{|c|c|c|c|c|c|c|}
\hline Параметр & Проект & $\begin{array}{c}\text { Рівень } \\
\text { варіації } \\
\text { параметрів } \\
\end{array}$ & $\begin{array}{c}\text { Середнє } \\
\text { значення, } \\
M(\mathrm{x}) \\
\end{array}$ & $\begin{array}{c}\text { Стандартне } \\
\text { відхилення, } \\
\sigma \\
\end{array}$ & $\begin{array}{c}\text { Коеф. } \\
\text { варіації, } \\
v_{N P V}\end{array}$ & $\begin{array}{c}\text { Число- } \\
\text { випадків } \\
N P V<0\end{array}$ \\
\hline 1 & 2 & 3 & 4 & 5 & 6 & 7 \\
\hline \multirow{9}{*}{$Q$, шт. } & \multirow{3}{*}{ A } & $10 \%$ & 20310 & 1166,13 & $5,74 \%$ & $\mathrm{x}$ \\
\hline & & $20 \%$ & 20308 & 2332,54 & $11,49 \%$ & $\mathrm{x}$ \\
\hline & & $30 \%$ & 20278 & 3519,20 & $17,35 \%$ & $\mathrm{x}$ \\
\hline & \multirow{3}{*}{ B } & $10 \%$ & 9811 & 562,58 & $5,73 \%$ & $\mathrm{x}$ \\
\hline & & $20 \%$ & 9800 & 1136,45 & $11,60 \%$ & $\mathrm{x}$ \\
\hline & & $30 \%$ & 9793 & 1695,64 & $17,31 \%$ & $\mathrm{x}$ \\
\hline & \multirow{3}{*}{$\mathrm{C}$} & $10 \%$ & 14967 & 855,52 & $5,72 \%$ & $\mathrm{x}$ \\
\hline & & $20 \%$ & 14961 & 1729,69 & $11,56 \%$ & $\mathrm{x}$ \\
\hline & & $30 \%$ & 14965 & 2598,44 & $17,36 \%$ & $\mathrm{x}$ \\
\hline \multirow{9}{*}{$\begin{array}{c}P 3, \\
\text { грн./шт. }\end{array}$} & \multirow{3}{*}{ A } & $10 \%$ & 50,40 & 3,07 & $6,10 \%$ & $\mathrm{x}$ \\
\hline & & $20 \%$ & 50,45 & 6,15 & $12,20 \%$ & $\mathrm{x}$ \\
\hline & & $30 \%$ & 50,45 & 9,24 & $18,32 \%$ & $\mathrm{x}$ \\
\hline & \multirow{3}{*}{ B } & $10 \%$ & 179,91 & 10,86 & $6,03 \%$ & $x$ \\
\hline & & $20 \%$ & 180,28 & 22,02 & $12,22 \%$ & $x$ \\
\hline & & $30 \%$ & 180,38 & 33,05 & $18,32 \%$ & $\mathrm{x}$ \\
\hline & \multirow{3}{*}{$\mathrm{C}$} & $10 \%$ & 93,58 & 5,66 & $6,05 \%$ & $\mathrm{x}$ \\
\hline & & $20 \%$ & 93,50 & 11,40 & $12,19 \%$ & $\mathrm{x}$ \\
\hline & & $30 \%$ & 93,44 & 17,18 & $18,38 \%$ & $\mathrm{x}$ \\
\hline
\end{tabular}


Продовження табл. 2

\begin{tabular}{|c|c|c|c|c|c|c|}
\hline 1 & 2 & 3 & 4 & 5 & 6 & 7 \\
\hline \multirow{9}{*}{$\begin{array}{l}V C, \\
\text { грн./шт. }\end{array}$} & \multirow{3}{*}{ A } & $10 \%$ & 24,98 & 1,44 & $5,76 \%$ & $\mathrm{x}$ \\
\hline & & $20 \%$ & 25,02 & 2,89 & $11,55 \%$ & $\mathrm{x}$ \\
\hline & & $30 \%$ & 24,99 & 4,33 & $17,33 \%$ & $\mathrm{x}$ \\
\hline & \multirow{3}{*}{ B } & $10 \%$ & 115,02 & 6,67 & $5,80 \%$ & $\mathrm{x}$ \\
\hline & & $20 \%$ & 114,89 & 13,26 & $11,54 \%$ & $\mathrm{x}$ \\
\hline & & $30 \%$ & 115,02 & 19,97 & $17,36 \%$ & $\mathrm{x}$ \\
\hline & \multirow{3}{*}{$\mathrm{C}$} & $10 \%$ & 54,96 & 3,17 & $5,77 \%$ & $\mathrm{x}$ \\
\hline & & $20 \%$ & 55,05 & 6,38 & $11,58 \%$ & $\mathrm{x}$ \\
\hline & & $30 \%$ & 54,87 & 9,48 & $17,27 \%$ & $\mathrm{x}$ \\
\hline \multirow{9}{*}{$\begin{array}{l}\mathrm{T}, \\
\text { років }\end{array}$} & \multirow{3}{*}{ A } & $10 \%$ & 3,00 & 0,17 & $5,74 \%$ & $\mathrm{x}$ \\
\hline & & $20 \%$ & 3,00 & 0,35 & $11,52 \%$ & $\mathrm{x}$ \\
\hline & & $30 \%$ & 2,99 & 0,52 & $17,32 \%$ & $\mathrm{x}$ \\
\hline & \multirow{3}{*}{ B } & $10 \%$ & 3,00 & 0,17 & $5,76 \%$ & $\mathrm{x}$ \\
\hline & & $20 \%$ & 3,00 & 0,35 & $11,55 \%$ & $\mathrm{x}$ \\
\hline & & $30 \%$ & 3,00 & 0,52 & $17,36 \%$ & $\mathrm{x}$ \\
\hline & \multirow{3}{*}{$\mathrm{C}$} & $10 \%$ & 3,00 & 0,17 & $5,71 \%$ & $\mathrm{x}$ \\
\hline & & $20 \%$ & 3,01 & 0,35 & $11,55 \%$ & $\mathrm{x}$ \\
\hline & & $30 \%$ & 3,00 & 0,52 & $17,28 \%$ & $\mathrm{x}$ \\
\hline \multirow{9}{*}{$N P V$, грн. } & \multirow{3}{*}{ A } & $10 \%$ & 271314,07 & 113333,49 & $41,77 \%$ & 17 \\
\hline & & $20 \%$ & 269914,24 & 229446,59 & $85,01 \%$ & 1283 \\
\hline & & $30 \%$ & 267014,16 & 345376,77 & $129,35 \%$ & 2358 \\
\hline & \multirow{3}{*}{ B } & $10 \%$ & 268280,39 & 201279,94 & $75,03 \%$ & 1020 \\
\hline & & $20 \%$ & 275022,86 & 406600,24 & $147,84 \%$ & 2577 \\
\hline & & $30 \%$ & 268295,03 & 615831,51 & $229,54 \%$ & 3438 \\
\hline & \multirow{3}{*}{$\mathrm{C}$} & $10 \%$ & 269969,61 & 157428,75 & $58,31 \%$ & 375 \\
\hline & & $20 \%$ & 263901,13 & 316622,75 & $119,98 \%$ & 2151 \\
\hline & & $30 \%$ & 265336,08 & 481389,33 & $181,43 \%$ & 3102 \\
\hline
\end{tabular}

Джерело: власна розробка авторів

Одновимірні розподіли параметрів не дозволяють врахувати кореляцію. Тому 3 метою з'ясування питання про вплив кореляції на $N P V$ застосували багатовимірну імітацію [47], зв'язавши номінальні ціни функціональною залежністю виду:

$$
P_{t}=P_{l}(1+r)^{t} \text {. }
$$

де $P$ і $P$ початкова і кінцева ціни, відповідно. Як встановлено в [47], безперервний вектор $\vec{\theta}=\left(\theta_{1}, \ldots, \theta_{\mathrm{m}}\right)^{\mathrm{T}}$ бу де розподіленим за нормальним законом, якщо його щільність описуватиметься такою залежністю:

$$
f_{\bar{\theta}}(\vec{X})=\frac{1}{\sqrt{(2 \pi)^{m}|R|}} \cdot \exp \left[-\frac{1}{2} \varphi(\vec{X})\right] .
$$

Тут $\varphi(\vec{X})=(\vec{X}-\vec{M})^{T} R^{-1}(\vec{X}-\vec{M}) ; \vec{X}^{T}=\left(x_{1}, \ldots, x_{m}\right)-m$-вимірний вектор-рядок аргументів щільності ймовірностей; $\vec{M}^{T}=\left(M_{1}, \ldots, M_{m}\right)-m$-вимірний вектор-рядок математичних очікувань; $R=\left(R_{i j}\right)(i, j=\overline{1, m}$ - симетрична невід'ємна $(m \times m)$ коваріаційна матриця; $|R|=\operatorname{det} R$.

Рівняння $\varphi(\vec{X})=G$ відповідає гіперповерхні в $R^{m}$ просторі, а при $G=m+2-$ еліпсоїду розсіювання нормального розподілу, об'єм якого пропорційний кореню квадратному з визначника коваріаційної матриці [46]:

$$
V=(m+2)^{m / 2} \pi^{m / 2} \sqrt{|R|} / \Gamma(m / 2+1),
$$


де $\Gamma(m / 2+1)$ - гама функція. Для заданих дисперсій компонент випадкового вектору цей об'єм буде найбільшим, коли його компоненти не корельовані (матриця $R-$ діагональна). В умовах генерації багатовимірного нормального розподілу [19], коли $L L^{T}=R\left(L=\left(L_{i j}\right)\right.$ - дійсна $(m \mathrm{x} m)$ матриця), випадковий вектор має вигляд:

$$
\vec{\theta}=L \cdot \vec{\zeta}+\vec{M},
$$

де $\overrightarrow{\boldsymbol{\zeta}}=\left(\varsigma_{1}, \ldots, \zeta_{m}\right)^{T}$ - стандартний $m$-вимірний вектор Гауса, компоненти якого мають нормальний розподіл $N(\vec{M}, R)$. За матрицю $L$ вибрали нижню трикутну ( $L_{i j}=0$, якщо $j>1$ ). Однозначний розв'язок рівняння (22) отримали за розкладом А-Л. Холецького [63], обчисливши елементи $L_{i j}$ цісї матриці за такою рекурентною формулою:

$$
\begin{array}{ll}
L_{i j}=\frac{R_{i j},}{L_{j j}}, & i=\overline{j+1, n} ; \\
L_{j j}=\sqrt{R_{j j}}, & j=\overline{1, n-1 .}
\end{array}
$$

Далі використали алгоритм багатовимірної імітації, згенерувавши кожнуккомпоненту вектора $\vec{\zeta}$ окремо, і знайшли нижню трикутну матрицю $L$. Вектор $\vec{\theta}$, що розподілений за багатовимірним нормальним законом, розрахували за формулою (22). Ціни розрахували за формулою (19). У табл.. 3 наведені верхня трикутна частина кореляційної матриці компонентів $N P V$ проекту А для варіації параметрів у $20 \%$, коли $P_{1}=P_{2}=P_{3}$, і нижня трикутна частина кореляційної матриці параметрів того ж проекту. Помічаємо, шо нижня кореляційна матриця суттєво відрізняється від верхньої в частині кореляції цін зі ставкою дисконтування (помічено темним). Враховуючи цю

Таблиия 3

Порівняння кореляційних матриць параметрів $N P V$ для двох варіантів формування цін (пояснення у тексті)

\begin{tabular}{|c|c|r|r|r|r|r|r|}
\hline & $Q$ & $P 1$ & $P 2$ & \multicolumn{1}{c|}{$P 3$} & $V C$ & \multicolumn{1}{c|}{$\hat{r}$} & \multicolumn{1}{c|}{$T$} \\
\hline$Q$ & 1,00000 & 0,00310 & 0,00173 & 0,00043 & $-0,00302$ & $-0,01215$ & $-0,00656$ \\
\hline$P 1$ & & 1,00000 & 0,98620 & 0,94833 & 0,00208 & $-0,00381$ & 0,00823 \\
\hline$P 2$ & & & 1,00000 & 0,98777 & 0,00329 & 0,15349 & 0,00856 \\
\hline$P 3$ & & & & 1,00000 & 0,00329 & 0,15349 & 0,00856 \\
\hline$B C$ & & & & & 1,00000 & 0,00408 & $-0,00128$ \\
\hline$\hat{r}$ & & & & & & 1,00000 & 0,00492 \\
\hline$t$ & & & & & & & 1,00000 \\
\hline$Q$ & 1,00000 & & & & & & \\
\hline$P 1$ & 0,00621 & 1,00000 & & & & & \\
\hline$P 2$ & 0,00442 & 0,99971 & 1,00000 & & & & \\
\hline$P 3$ & 0,00310 & 0,99910 & 0,99983 & 1,00000 & & & \\
\hline$B C$ & $-0,00602$ & 0,00510 & 0,00526 & 0,00539 & 1,00000 & & \\
\hline$\hat{r}$ & $-0,01615$ & 0,78238 & 0,79542 & 0,80515 & 0,00450 & 1,00000 & \\
\hline$t$ & $-0,01313$ & 0,02530 & 0,02553 & 0,02570 & $-0,00236$ & 0,02711 & 1,00000 \\
\hline
\end{tabular}

Джерело: власна розробка авторів

обставину, виконали процедуру Монте-Карло з імітацією множинного розподілу параметрів $N P V$ і порівняли їх з результатами одновимірної моделі.

При цьому використали додатково такі два критерії вибору проектів: а) чиста вартість невизначеності для інвестора в разі відхилення проекту - це середня величина $N P V$, що перевищує нуль $(\overline{N P V}>0$ грн.) і б) імовірність отримання від'ємної $N P V$ - це число випадків отримання від' ємного $N P V *$ імовірність одного прогону $=\mathrm{n}_{\mathrm{NPV}<0} * 100 \% / 10000, \mathrm{P}(\mathrm{NPV}<0), \%$. Результати досліджень зведені в табл. 4. 
Величини поправок, що привнесені множинним розподілом $N P V$ для розглянутих інвестиційних проектів, представлені у двох правих крайніх стовпщях. Видно, що ці поправки не носять систематичного характеру й можуть досягати $10 \%$ (на рівнях $30 \%$ варіації параметрів). Отже, проект А залишається найменш ризиковим серед розглянутих, оскільки значення знайдених додаткових критеріїв $\overline{N P V}>0$ і $P(N P V<0)$ для нього найменші. Використавши далі формулу (9), оцінили похибки розрахунків величини $N P V$ для проекту А. Встановлено, що для трьох варіантів діапазону варіації парамет-

Таблиия 4

Зведені результати аналізу інвестиційних проектів методом Монте-Карло

\begin{tabular}{|c|c|c|c|c|c|}
\hline \multirow[t]{2}{*}{ Параметр } & \multirow[t]{2}{*}{ Проект } & \multirow{2}{*}{$\begin{array}{c}\text { Рівень } \\
\text { варіації } \\
\text { параметрів }\end{array}$} & \multirow[t]{2}{*}{ Значення } & \multicolumn{2}{|c|}{$\begin{array}{l}\text { Величина } \\
\text { поправки }\end{array}$} \\
\hline & & & & Aбс. & Відн. \\
\hline \multirow{9}{*}{$\overline{N P V}$, грн. } & \multirow{3}{*}{ A } & $10 \%$ & 271314,07 & $-2012,75$ & $-0,74 \%$ \\
\hline & & $20 \%$ & 269914,24 & $-7830,55$ & $-2,90 \%$ \\
\hline & & $30 \%$ & 267014,16 & $-17175,81$ & $-6,43 \%$ \\
\hline & \multirow{3}{*}{ B } & $10 \%$ & 268280,39 & $-2954,95$ & $-1,10 \%$ \\
\hline & & $20 \%$ & 275022,86 & $-12696,30$ & $-4,62 \%$ \\
\hline & & $30 \%$ & 268295,03 & $-29188,92$ & $-10,88 \%$ \\
\hline & \multirow{3}{*}{$\mathrm{C}$} & $10 \%$ & 269969,61 & $-2346,41$ & $-0,87 \%$ \\
\hline & & $20 \%$ & 263901,13 & $-9721,35$ & $-3,68 \%$ \\
\hline & & $30 \%$ & 265336,08 & $-21215,94$ & $-8,00 \%$ \\
\hline \multirow{9}{*}{$\overline{N P V}>0$, грн. } & \multirow{3}{*}{ A } & $10 \%$ & 271944,97 & $-2076,37$ & $-0,76 \%$ \\
\hline & & $20 \%$ & 322200,61 & 7361,39 & $2,28 \%$ \\
\hline & & $30 \%$ & 401210,62 & 10774,85 & $2,69 \%$ \\
\hline & \multirow{3}{*}{$\mathrm{B}$} & $10 \%$ & 315090,30 & 7849,69 & $2,55 \%$ \\
\hline & & $20 \%$ & 452594,21 & 18267,64 & $4,04 \%$ \\
\hline & & $30 \%$ & 612508,18 & 24993,80 & $4,07 \%$ \\
\hline & \multirow{3}{*}{$\mathrm{C}$} & $10 \%$ & 281915,50 & 2609,26 & $0,93 \%$ \\
\hline & & $20 \%$ & 380131,44 & 13671,19 & $3,60 \%$ \\
\hline & & $30 \%$ & 509808,76 & 17979,35 & $3,53 \%$ \\
\hline \multirow{9}{*}{$P(N P V<0), \%$} & \multirow{3}{*}{ A } & $10 \%$ & $0,22 \%$ & $-0,02 \%$ & $-9,09 \%$ \\
\hline & & $20 \%$ & $12,83 \%$ & $2,90 \%$ & $22,60 \%$ \\
\hline & & $30 \%$ & $23,58 \%$ & $2,89 \%$ & $12,26 \%$ \\
\hline & \multirow{3}{*}{ B } & $10 \%$ & $10,20 \%$ & $2,19 \%$ & $21,47 \%$ \\
\hline & & $20 \%$ & $25,77 \%$ & $2,22 \%$ & $8,61 \%$ \\
\hline & & $30 \%$ & $34,38 \%$ & $2,18 \%$ & $6,34 \%$ \\
\hline & \multirow{3}{*}{$\mathrm{C}$} & $10 \%$ & $3,75 \%$ & $1,42 \%$ & $37,87 \%$ \\
\hline & & $20 \%$ & $21,51 \%$ & $2,65 \%$ & $12,32 \%$ \\
\hline & & $30 \%$ & $31,01 \%$ & $2,23 \%$ & $7,19 \%$ \\
\hline
\end{tabular}

Джерело: власна розробка авторів

рів у $10 \%, 20 \%$ і $30 \%$ з ймовірністю $P=1$, похибки не виходять за межі $2,1 \%, 4,3 \%$ і $6,5 \%$, відповідно. Якщо додати квадрати цих величин і значення $P(N P V<0)$, виправлених на множинний розподіл, отримаємо оцінки ризиків для проекту $\mathrm{A}$ :

- $\sqrt{(0,22-0,02)^{2}+2,1^{2}}=2,11 \%$ для рівня варіації параметрів $10 \%$.

- $\sqrt{(12,83+2,90)^{2}+4,3^{2}}=16,31 \%$ для рівня варіації параметрів $20 \%$.

- $\sqrt{(23,58+2,89)^{2}+6,5^{2}}=27,26 \%$ для рівня варіації параметрів $30 \%$. 
Слід наголосити також, що отримані в $M S$ Excel результати аналогічні результатам, отриманим у ET Google Docs, доступ до яких можливий за адресою:

https: /docs.google.com/spreadsheets/d/1m_תGWNP_JWQdA8pwgCgVM7Xp TnP9AZpVMwLD7dSqS10/edit\#gid=0.

Отже, у цій статті методом модуляції Монте-Карло досліджено вибір інвестиційних проектів зі слабкою і сильною кореляцією параметрів чистої приведеної вартості за наявності ризику.

\section{Висновки}

1. Обгрунтовано з використанням електронних таблиць MS Excel / Google Docs методику вибору інвестиційних проектів методом Монте-Карло як для слабо, так і сильно корельованих параметрів $N P V$ за наявності ризику.

2. Виявлено методом Монте-Карло чітку градацію інвестиційних проектів за ризиком, що аналогічна знайденій за коефіцієнтами еластичності. Показано, що цей метод $€$ більш інформативним щодо ймовірнісних показників.

3. Встановлено, що при виборі інвестищійного проекту необхідно враховувати кореляційні ефекти, використовуючи багатовимірну імітацію.

\section{Список використаних джерел}

1. Брігхем Є. Ф. Основи фінансового менеджменту / пер. 3 англ. В. Біленький, О. Медвідь, С. Лазаренко, Ж. Чуприна, В. Побелинський. К.: КП «ВАЗЬКО» Молодь. 1977. $1000 \mathrm{c}$.

2. Райс Г., Койли Б. Финансовые инвестиции и риск / сокр. пер. с англ. под ред. М. А. Гольцберга. К.: БХВ-КИЕВ, 1995. 590 с.

3. Бирман Г., Шмидт С. Экономический анализ инвестиционных проектов / пер. с англ. под. ред Л. П. Белых. М.: Банки и биржи, ЮНИТИ, 1997. 631 с.

4. Ван Хорн Дж. К. Основы управления фінансами / пер. с англ. гл. ред. серии Я. В. Соколов. М.: Финансы и статистика, 2000.800 с.

5. Шарп У., Александер Г., Бейли Дж. Инвестиции. М.: ИНФРА, 1997. 1024 с.

6. Маршалл Д. Ф., Бансал К. Финансовая инженерия. М.: Инфра-М, 1998. 784 с.

7. Фабоцци Ф. Д. Управление инвестициями: [у 2 т. ]. М.: Инфра-М, 2000. 932 с.

8. Беренс В., Хавранек П. М. Руководство по оценке эффективности инвестиций. М.: Интерэкспресс, Инфра-М, 1995. 528 с

9. Ковалев В. В. Введение в финансовый менеджмент. М.: Финансы и статистика, $2000.768 \mathrm{c}$.

10. Виленский П. Л., Лившиц В. Н., Смоляк С. А. Оценка эффективности инвестиционных проектов. Теория и практика: учеб. пособ. [2-е изд. перераб. и доп.]. М.: Дело, 2002. 888 с.

11. Powel S., Baker K. R. Management Science: The Art of Modeling with Spreadsheets. John Wiley and Sons. 2004. 567 P.

12. Карлберг К. Бизнес-анализ с помощью Excel. Диалектика. 1997. 448 с.

13. Орлова И. В. Экономико-математические методы и модели. Выполнение расчетов в среде Excel: практикум. М.: ЗАО «Финстатинформ», 2000. 136с.

14. Дубров А. М., Лагоша Б. А., Хрусталев Е. Ю., Бариновская Т. П. Моделиование рискових ситуаций в экономике и бизнесе: учеб. пособ. М.: Финансы и статистика. 2001. $224 \mathrm{c}$.

15. Афоничкин А. И., Акимов В. Л., Афоничкина Е. А. Разработка бизнес-приложений в экономике на базе MS Excel. М.: ДИАЛОГ-МИФИ. 2003. 416 с.

16. Черняк А. А., Новиков В.А., Мельников О. И., Кузнецов А. В. Математика для экономистов на базе Mathcad. СПб.: БХВ-Петербург. 2003. 496 с.

17. Леоненков А. В. Решение задач оптимизации в среде MS Excel. СПб. : БХВПетербург. 2005. 704 с.

18. Гришин А. В., Котов-Дарти С. Ф., Ягунов В. Н. Статистические модели в экономике. Ростов-на-Дону: Феникс, 2005. 344 с.

19. Матвійчук А. В. Аналіз і управління економічним ризиком: навч. посіб. К.: Центр навчальної літератури, 2005. 224 с. 
20. Томашевський В. М., Жданова О. Г., Жданов О. О. Вирішення практичних завдань методами комп'ютерного моделювання: навч. посіб. К.: Корнійчук, 2001. 268 с.

21. Бенькович Е. С. Практическое моделирование динамических систем. СПб.: БХВПетербург, 2002. 464 с.

22. Емельянов А. А., Власова Е. В., Дума Р. В. Имитационное моделирование экономических процессов : учеб. пособ. М.: Финансы и статистика, 2002. 368 с.

23. Гусева Е. Н. Имитационное моделирование экономических процессов в бреде ARENA/Е.Н. Гусева. М.: ФЛИНТА, 2016. 133 с.

24. Гультяев A. К. Matlab 5.2 Имитационное моделирование в среде Windows: практ. пособ. М.: Наука, 1990. 286 с.

25. Малярець Л. М., Резнік С. В. Математика для економістів (практичний посібник до розв'зання задач економічних досліджень у MatLab). X.: XHEУ, 2008. 211 c.

26. [Електронний ресурc]URL: www oracle-crystal-ball.updatestar/com/ Останнє звернення 22.04.2017.

27. Palisade. http://go.palisade.com/RISKDownload.html. Останнє звернення 25.04.2017.

28. Лукашов А. В. Метод Монте-Карло для финансовых аналитиков: кратк. путевод. // Управление корпоративными фінансами, №1(19). 2007. С. 22-39.

29. Жданчиков П. А. Как научиться строить бизнес-план в Project Expert. M.: NT Press, 2006. $208 \mathrm{c}$.

30. Штовба С. Д. Проектирование нечетких систем средствами Matlab. M.: Горячая линия-Телеком, 2007. 288 с.

31. Леоненков А. В. Нечеткое моделирование в среде Matlab и Fuzzy Tech. СПб. БХВПИТЕР. 2005. $724 \mathrm{c}$.

32. Кобелев Н. Б. Имитационное моделирование объектов с хаотическими параметрами: учеб. пособ. М.: Инфра-М. 2016. 192 с.

33. Сіницький М. Є. Хмарні технології у фінансово-статистичних розрахунках: навч. посіб. К.: ДП «Інформ.-аналіт. агентство». 2016. 564 с.

34. Fisher I. The Rate of Interest/ I. Fisher. N.-Y. : The MacMillan Company, 1907. 442 p. URL: http://www.socserv2.socsi.mcmaster.ca/ econ/ugcm/3ll3/fisfer/RateofInterest. pdf . Останне звернення 25.04.2017.

35. Fisher I. The Theory of Interest/ I. Fisher. N.-Y. : The MacMillan Company, 1930. 428 p. URL: http://economlib.org/library/YPDBooks/Fisher/fshToI.html. Останнє звернення 25.04.2017.

36. Коефіцієнт еластичності та методи його підрахунку. URL: https://studme.com.ua/.../koeffitsient_elastichnosti_metody_ego_podscheta. htm

37. Бурдун Г. Д., Марков Б. Н. Основы метрологи: учеб. пособ. для вузов. М.: Изд-во стандартов, $1972.312 \mathrm{c}$.

38. Metropolis N., Ulam S.The Monte-Carlo Method // J. Amer. Statistical assoc., 1949. Vol.44, N0247. P. 335-341.

39. Diaconis Persi. The Markov chain Monte Carlo revolution. J.: Bull. Amer. Math. Soc., 2009. Vol. 46 (2). P. 179-205.

40. Моцний Ф. В. Сучасний базовий інструментарій математичної статистики: у 2-х ч. (Ч. І. Основні поняття математичної статистики//Науковий Вісник НАСОА. 2015. №2. С.16-29; Ч. II. Вибрані характеристики статистичних розподілів // Науковий Вісник НАСОА. 2015. №3. С.14-25.

41. Моцний Ф. В. Курс лекцій з теорії ймовірностей: навч. посіб. К.: ДП «Інформ.аналіт. агентство», 2013. $205 \mathrm{c}$.

42. Закон великих чисел та центральна гранична теорема. URL://moodle/ipo.kpi.ua/ $\mathrm{mod} / \mathrm{resource} / \mathrm{view} / \mathrm{php} ? \mathrm{r}$...

43. Kom R., Korn E., Kroisandt G. Monte Carlo Methods and Models in Finance and Insurance. Chapman \& Hall / CRC Press Financial Mathematics Series. 2010. 484 p.

44. Войтишек А. В. Основы метода Монте-Карло : учеб. пособ. Новосибирск, изд-во НГУ, 2010. $108 \mathrm{c}$.

45. Ермаков С. М. Статистическое моделирование: 2-е изд. доп. М.: Наука, 1982. $296 \mathrm{c}$. 
46. Некруткин В. В. Моделирование распределений. Кафедра статистического моделирования, матмех СПбГУ. Материал к специальному курсу. 2014. 100 с. URL: http://www.twirpx.com/file/1844525/. Останнє звернення 10.05.2017.

47. Мартышенко С. Н., Мартышенко Н. С., Кустов Д. А. Моделирование многомерных данных и компьютерный эксперимент // Техника и технология, 2007. №2 . С. 47-52.

48. Конгруентный метод формирования псевдослучайных чисел.URL: //cppstudio. $\mathrm{com} / \mathrm{post} / 1296 /$

49. Matsumoto M. Nishimura T. Mersenne twister: A 623-dimensionally equidistributed uniform pseudorandom number generator //ACM Trans. on Modeling and Computer Simulations, 1998. №8 (1). P. 3-30.

50. Наиболее распространенные распределения непрерывных случайных величин // Распределение: образовательній математический сайт URL:...old.exponenta.ru/ educat/class/tv/theme $0 / 5$.asp.

51. Хаббард Дуглас У. Как измерить все, что угодно. Оценка стоимости нематериального бизнеса. М.: Олима бізнес, 2009. $320 \mathrm{c}$.

52. Тараскин А. Ф. Статистическое моделирование методом Монте-Карло учеб. пособ. Самара, 1977. $61 \mathrm{c}$.

53. Оценка точности характеристик, полученых методом Монте-Карло. Необходимое число реализаций. URL://stu.sernam.ru/book_rop.php?id=91.

54. Шведов А. С. О математических методах при работе с аукционами. //Экономический журнал ВЭШ. 1996. №3. С.385-409.

55. Облакова А. В., Тригуб И. В. Моделирование инвестиционных процессов в секторе телекоммунакационных услуг. URL: simulation.su/uploads//.../im$\bmod -2007-2-147-151 / p d f$.

56. Ефремова Е. А., Прядкина В. А. Применение метода Монте-Карло для оценки инвестиционных проектов. URL: http://sibac/info/studconf/econom/XXVII40330.

57. Liang Jin, Zhou Peng, Zhou Yujing, Ma Junmei. Valiation of ctedit default with counterparty default risk by structual model //Applied Mathematics. 2011. Vol.3. P.106-117.

58. Wu Yunna, Xinliang Hu, Yue Shen. The application of Monte Carlo Method Simulation // Advance in Computation Environment Science. 2012. P.207-211.

59. Pedersen M. E. H. Hvass . Portfolio optimization\&Monte Carlo simulation // Hvass Laboratories Report. 2014. HL-1401.

60. Женова Н. А. Метод Монте-Карло в инвестиционном проектировании // Вестник Ростовского торгово-єкономического университета. 2014. №11(90). С.42-51.

61. Сазонова А. А., Сазонова М. В. Применение метода Монте-Карло для моделирования экономических рисков в проектах // Наука и современность. 2016. С.228-232.

62. Constantinescu V. P. A. Monte Carlo Method in Risk Analysis for Investment Projects // Procedia Economics and Finance, 2014. Vol.15. PP.393-400.

63. Разложение Холецкого (метод квадратного корня). URL: algowiki-project.org/.../ Разложение_Холецкого_(метод_квадратного_корня). 
Н. Е. СИНИЦКИЙ,

кандидат физико-математических наук, доиент кафедры информационных систем и технологий, Национальная академия статистики, учета и аудита Ф. В. МОІЦНЫЙ,

доктор физико-математических наук, профессор, заведуюиий кафедрой прикладной математики, Национальная академия статистики, учета и аудита

\section{Выбор инвестиционных проектов методом Монте-Карло при наличии риска}

Рассмотрена балансная модель инвестиционного проекта с дисконтированием. Проведен анализ проектов со слабой и сильной корреляцией параметров чистой приведеной стоимости. Выявлена методом Монте-Карло четкая градация проектов по риску. Установлено, что при выборе проекта необходимо учитывать корреляционные эффекты, использовав многомерную имитацию.

Ключевые слова: инвестиционный проект, чистая приведенная стоимость., риски, метод Монте-Карло, псевдослучайньле числа, разложение А-Л. Холечкого, погреиности моделирования.

\section{E. SINYTSKYI, \\ PhD (Phys. \&Math.) Associate Professor of Information Systems and Technology Department, National Academy of Statistics, Accounting and Audit F. V. MOTSNYI, \\ Dr. Sc. (Phys. \&Math.), Professor, Head of the Department for Applied Mathematics, National Academy of Statistics, Accounting and Audit}

\section{Selection of Investment Projects by Monte Carlo Method in Risk Condition}

The Monte Carlo method (also known as the Monte Carlo simulation) was proposed by Nicholas Metropolis, S. Ulam and Jhon Von Neiman in 40-50-th years of the past century. The method can be widely applied to analysis of investment projects due to the advantages recognized both by practitioners and the academic community. The balance model of a project with discounted financial flow's has been studied. The Monte Carlo model for project with low and high correlated net present value (NPV) parameters has been implemented for Microsoft Excel and Google Docs spread-sheet solution. A distinct graduation of risk was identified. A necessity of account of correlation effects and the use of multivariate imitation during the project selection has been demonstrated.

Keywords: investment project, net present value (NPV), risk, the Monte Carlo method (the Monte Carlo simulation method), pseudorandom numbers, Choletsky's expansion, simulation errors.

Посилання на статтю:

Сіницький М. Є., Моцний Ф. В.Вибір інвестиційних проектів методом МонтеКарло за наявності ризику // Науковий вісник Національної академії статистики, обліку та аудиту: зб. наук. праць. 2017. №1-2. С. 100-112.

У збірнику наукових праць «Науковий вісник Національної академії статистики, обліку та ау диту» №4, 2016 на с. 39 помилково було наведено рівняння: Уdox=pq (2).

Вірне рівняння: aq $2+(\mathrm{b}-\mathrm{p}) \mathrm{q}+\mathrm{c}=0$ (2) 